\title{
X-ray fluorescence technique for studying mineral nutrients of Quinoa seed cultivated in Iraq.
}

Raghdan H. Mohsin ${ }^{1}$, Risala H. Allami², Raghad S. Mouhamad ${ }^{3}$.

DOl. 10.21931/RB/2019.04.04.4

Abstract: Quinoa (Chenopodium quinoa Wild) is a plant that recently has been successfully grown in Iraq, providing seeds rich in nutrients and bioactive compounds. The distribution of metal composition and amino acid value in the quinoa seed was determined using the X-Ray Fluorescence technique. The present study aimed at the characterization of chemical composition, nutritional value, and amino acid profiles of quinoa seed cultivated in Iraq. Moisture, ash, gross fat, gross protein, gross fiber and carbohydrate contents concerning quinoa seeds were ranged from $9.45 \pm 0.22 \%, 2.13 \pm 0.045 \%, 6.4 \pm 0.043 \%, 6.4 \pm 0.873$ $\%$ \% $3.8 \pm 0.044 \%$ to1.67+68.1 \% respectively. The current study was undertaken to Detection of active compounds in quinoa seed extract including, alkaline, flavonoids, phenols, glycosides, resins, and tannins, where all the findings were positive. It could be concluded that quinoa seed, cultivated in Iraq are a good source of essential nutrients such as minerals, essential amino acids.

Key words: Chenopodium; chemical composition; nutrition; amino acids.

\section{Introduction}

Quinoa is a grain-like food nowadays referred to as a pseudo-cereal ${ }^{1}$. Its use as food is dated back to the Andean civilization, and presently it is cultivated in different environmental conditions ${ }^{2}$. Besides their high nutritional value, quinoa seeds (QS) are rich sources of different phytochemicals ${ }^{3}$. A recent study reported that a serving portion of quinoa $(-40$ g) meets an enormous piece regarding the everyday advocated consumption because of necessary vitamins - commonly vitamins, minerals, and then essential amino acids ${ }^{4}$. Quinoa comminute is suitable for education about special food-stuffs then among precise bakery products (bread, cookies, biscuits, noodles, pasta, pancakes, or others $)^{5}$, as much correctly as like fermented merchandise ${ }^{6}$. In the meanwhile, quinoa has been swiftly being attention as much a functional food; thus its chemical parts or drug properties had been currently spotlighted ${ }^{7}$. The Food and Agriculture Organization of the United Nations (FAO) launched the worldwide year regarding quinoa in 2013 in conformity with civilizing the manufacturing and revalorization of this valuable crop ${ }^{8}$. Quinoa is prosperous in protein, lipids, and $\mathrm{ash}^{9}$. Their high protein content material thoroughness beside 13.1 by $16.7 \%$ and is higher than those about rice, barley, corn, and rye and shut according to so much about wheat ${ }^{10}$. Quinoa protein is referred to in conformity with as a super protein together with higher content concerning lysine, methionine, and threonine in contrast after wheat and maize ${ }^{11}$. Carbohydrate content material concerning Quinoa is comparable in conformity with that regarding wheat, and starch is the principal carbohydrate element constituting 32\%-69\% of the handy carbohydrates $^{12}$. The content material regarding total dietary thread (7.0-11.7\%) and soluble string content (1.3-6.1\%) within quinoa seeds are nearer this in wheat ${ }^{13}$. Lipid content material concerning Quinoa (5.5-7.4\%) is higher than wheat (1.7\%) and behavior $(0.7 \%)$, building quinoa a sufficient supply of functional lipids ${ }^{14}$. Quinoa Comprise extra vitamin E, diet C, riboflavin (B2), pyridoxine (B6) and folic acid than wheat, rice, barley then grain $^{15}$, besides its high content material concerning calcium, magnesium, iron, copper, then zinc.

Moreover, calcium, magnesium, then potassium is discovered among quinoa in bio-available forms, for that reason their thing is considered in conformity with stay enough for a consistent food regimen ${ }^{16}$. Quinoa is gluten-free as is excellent because of the high-risk consumer crew together with celiac disease. Valuable bioactive compounds exhibiting anticancer, antiviral, antifungal, hypoglycemic hypocholesterolemia, antithrombotic, diuretic, and anti-inflammatory efficiency such as saponins hold been recognized of Quinoa ${ }^{17}$. Different polyphenols certain as phenolic acids, then flavonoids (quercetin, kaempferol or their glycosides) have been observed between Quinoa, as well ${ }^{18}$. Phytoecdysteroids between Quinoa are proven fitness talents together with anabolic, performance-enhancing, anti-osteoporotic, anti-diabetic, anti-obesity and shock recovery exercise ${ }^{19}$. The high nutritional value of quinoa seeds and their high content of bioactive components encouraged the planting of quinoa crops in Iraq. Therefore, the objective of this investigation was to characterize the chemical composition and nutritional value of seeds from Iraq, selected for their high yield and short cultivation period.

\section{Materials and methods}

\section{Samples collection of plant}

The Quinoa seeds were cultured in the college of Agriculture / Basrah University-Iraq. The seeds of the plants are adequately washed in tap water and then rinsed in distilled water. The rinsed leaves are dried in an oven at a temperature of 35$40^{\circ} \mathrm{C}$ for 3 days. The dried leaves of each plant are pulverized, using a sterile electric blender, to obtain a powdered form. The powdered kind of these plants is stored in airtight glass containers, protected from sunlight until required for analysis.

\section{Preparation of the extracts}

The extraction was performed by macerating $500 \mathrm{~g}$ in 1.5 $\mathrm{L}$ of ethanol $(70 \% \mathrm{v} / \mathrm{v})$ for one week with occasional stirring. The macerated mixture was filtered by filter paper and evaporated at $40^{\circ} \mathrm{C}$ up to one-third of the initial volume. The remaining solvent was evaporated entirely at $40^{\circ} \mathrm{C}$, using a hot air

\footnotetext{
${ }^{1}$ Basrah University- College of Agriculture, Iraq.

${ }^{2}$ Al-Nahrian University - College of biotechnology, Iraq.

${ }^{3}$ Ministry of science and technology Soil and Water Resources Center, Agricultural Research Directorate, Iraq.
} 
oven and kept in a desiccator for two days. The yield $(10 \% \mathrm{w} / \mathrm{w})$ of the powdered plant material was collected dried and stored at $5^{\circ} \mathrm{C}$ in an airtight container without light exposure. In the same vein, part of the pulverized sample was extracted with water only to made cold extract and with hot extract but the extraction at $50^{\circ} \mathrm{C}$, to evaluate the phytochemical constituents of hot and cold extracts with ethanolic extract, (the yield of bitter extract is $12 \%$, and for hot extract is $15 \% \mathrm{w} / \mathrm{w})^{21}$. Each plant powdered and plant extract sample was sieved through a $0.5 \mathrm{~mm}$ diameter sieve. A 5.0-gram powdered sample was used for XRF Studies. Triplicates of each sample were done ${ }^{22}$.

\section{Characterization of chemical composition}

The following A.O.A.C. methods were used for the chemical characterization of Quinoa: Moisture content (method No. 934.01) was determined by drying the appropriate amount of the sample in the oven (Tit Axon S.R.L via Canova, Italy) at 105 ${ }^{\circ} \mathrm{C}$ until constant weight ${ }^{20,21}$. Method No. 920.39 was applied for the determination of crude fat content using a Soxhlet apparatus (FRANK, England). Crude fiber content was measured with method No. 978.10, whereas oil protein content (method No. 990.03) was determined by the Kjeldahl apparatus (VELP, Italy). Ash content was measured via method No. 923.03 by heating samples in a muffle furnace at $550 \stackrel{\circ}{\circ}$ until constant weight ${ }^{21}$. Carbohydrate content was calculated according to Merrill and Kunerth ${ }^{21}$. Sodium, potassium and calcium content was determined by a flame photometer (PFP 7, Model Jenway 8515, England) applying method No.956.01, while magnesium, iron and zinc content material was once defined by way of atomic absorption spectroscopy (Perkin-ELMER, 2380, England) according to technique No. 968.08 of A.O.A.C. ${ }^{20}$.

\section{Evaluation using X-Ray Fluorescence (XRF)}

The crushed sow cloth was as soon as analyzed because of the content material of trace elements through Energy Dispersive X-ray Fluorescence (XRF) spectroscopy. The evaluation was once as soon as led abroad besides the Department of Geology, MSOT, Baghdad, Iraq. The original contract was determined via the usage concerning SPECTRO XPOS (Ametek cloth analysis division, Germany) with silicon weft detector SDD along with a resolution concerning one hundred forty-five $\mathrm{eV}$ at $\mathrm{x}$ zero pulses. The elementary spread for XRF spectroscopy is out of Sodium to Uranium. Triplicate experiments hold been celebrated because of each sample ${ }^{22}$

\section{Phytochemical analysis}

Chemical checks are carried out over the aqueous and ethanolic extracts powdered structure on the buried pattern of the usage of common methods ${ }^{21}$.

\section{Qualitative assessment concerning phytochemical constituents}

\section{Flavonoids Test}

A factor on crude lime used to be angry with $\mathrm{x} \mathrm{ml}$ about ethyl acetate over an air bathtub because of three min. The mixture was once filtered, yet four $\mathrm{ml}$ over the filtrate used to be shaken along $1 \mathrm{ml}$ regarding compounded ammonia solution and observed a yellow coloration ${ }^{20}$.

\section{Saponins Test}

$0.5 \mathrm{~g}$ about pointless powder old according to lie shaken together with water in a take a look at reed yet such was warmed between a water bathtub, then the persistent of froth shows the attendance of saponins ${ }^{20}$

\section{Tannins Test}

$0.5 \mathrm{~g}$ of the thick dust was mixed up including $\mathrm{x} \mathrm{ml}$ concerning distilled water. This was once filtered, and a $0.1 \%$ ferric chloride test was once brought in conformity with the filtrate, a blue-black coloration used to be indicated for the attendance of tannin ${ }^{20}$

\section{Anthraquinones Test}

$0.5 \mathrm{~g}$ concerning gross powder chronic in imitation of being shaken together with ten $\mathrm{ml}$ regarding benzene then was once filtered, $0.5 \mathrm{ml}$ regarding $x$ percent ammonia solution used to be delivered after the filtrate, then the mixture was once shaken well. The emergence of the violet coloration among the strata part indicates the availability concerning the anthraquinones ${ }^{20}$.

\section{Alkaloids Test}

$0.5 \mathrm{~g}$ about bold dust was defatted with $5 \%$ ethyl ether because of $15 \mathrm{~min}$. The defatted sample was once extracted because of 20 min along $5 \mathrm{ml}$ regarding aqueous $\mathrm{HCl}$ regarding a manifestation lotos bath. The resulting mixture was once centrifuged because of ten min at $3000 \mathrm{rpm} .1 \mathrm{ml}$ regarding the filtrate aged to stay dealt with including little drops concerning Mayer's test yet a $2 \mathrm{nd} 1 \mathrm{ml}$, including Dragendroff's analysis then turbidity used to be observed ${ }^{20}$.

\section{Phlobatannins Test}

An aqueous extract regarding every bury sample was as soon as boiled with $1 \%$ aqueous hydrochloric acid $(\mathrm{HCl})$ to education the deposition regarding the purple precipitate ${ }^{10}$.

\section{Terpenoids Test}

$5 \mathrm{ml}$ over aqueous extract over every inter pattern is blended with $2 \mathrm{ml}$ regarding $\mathrm{CHCl} 3$ into a check tube. Three $\mathrm{ml}$ about digested $\mathrm{H} 2 \mathrm{SO} 4$ is carefully brought following the combination per shape a layer. An interface including a reddish-brown coloration is customary salvo terpenoids constituent is present ${ }^{20}$.

\section{Glycosides Test}

$2 \mathrm{~g}$ concerning the pattern was once blended with $30 \mathrm{ml}$ on distilled lotus and such used to be crazed because of $5 \mathrm{~min}$ on a lot of baths, filtered or aged namely follows: $5 \mathrm{ml}$ regarding the filtrate was once as soon as delivered in accordance with $0.2 \mathrm{ml}$ regarding Fehling solution $A$ yet Fehling answer $B$ until it turns alkaline and agitated of a lotus bathtub because of $2 \mathrm{~min}$. A lightish blue coloration used in conformity with lie observed (instead of over brick pink precipitate) as suggests the penury on glycosides ${ }^{20}$.

\section{Qualitative analysis regarding photochemical constituents}

\section{Flavonoids standing}

$10 \mathrm{~g}$ regarding every gross bury powder used to be as soon as extracted persistently, including one hundred $\mathrm{ml}$ over $80 \%$ aqueous methanol at room temperature. The entire solution was as more quickly as filtered with the aid of Whatman filter delivery note no. Forty twins (125 m). The filtrate chronic according to keep other transferred of a crucible or thick in sinus and experienced in imitation of a steady weight ${ }^{20}$. 


\section{Saponins induction}

$20 \mathrm{~g}$ regarding pointless committed out of each drive into hold been to eke out of a conical flask or a hundred $\mathrm{cm}^{3}$ on $20 \%$ aqueous ethanol had been added. The samples were heated on a heat lotus bathtub because four $h$ along with continuous efficient at as regards fifty $5 \stackrel{\circ}{\circ}$. The aggregate was once filtered then the residue re-extracted along with partial sordid $200 \mathrm{ml}$ regarding 20\% ethanol. The mixed extracts bear been decreased after $40 \mathrm{ml}$ on a lot of baths at regarding ninety ${ }^{\circ} \mathrm{C}$. The hear used to be transferred into $250 \mathrm{ml}$ separator duty or $20 \mathrm{ml}$ of diethyl ether was as soon as delivered yet shaken vigorously. The aqueous strata used after keep healthy while the ether strata used to be once discarded. The purification system back under keeps repeating. $60 \mathrm{ml}$ regarding $\mathrm{n}$-butanol back in imitation of lie added. The blended n-butanol extracts were washed twice with $\times \mathrm{ml}$ over $5 \%$ aqueous sodium chloride. The final solution was as soon as angry within a water bath. After evaporation, the samples have been dried in the oven in imitation of constant weight than the saponin content used to be as soon as calculated ${ }^{20}$.

\section{Alkaloids determination}

For the strength of mind about perfect alkaloid content material fabric about sow then extracts, the reference method elects back according to be the altar concerning chelidonine content in accordance according to the German Pharmacopoeia ${ }^{20}$.

\section{Results and Discussion}

\section{Chemical composition of quinoa seeds}

Chemical structure of the investigated quinoa seeds from cultivated in Iraq and their energy values are within Table 1. permanency moisture, blatant fiber, ash, blatant fat, blatant protein or carbohydrate constitutes of Quinoa were ranged from $9.45 \pm 0.22 \%, 2.13 \pm 0.045 \%, 6.4 \pm 0.043 \%, 6.4 \pm 0.873$ $\%$ ، $3.8 \pm 0.044 \%$ ، to $1.67+68.1 \%$ respectively.

These results are very close to those observed in other studies $[12,25,30]$. In general, some of the analyzed parame-

\begin{tabular}{|c|c|}
\hline Organic structure & MSe \\
\hline Moisture & $9.45 \pm 0.22$ \\
\hline Ash & $2.13 \pm 0.045$ \\
\hline Crude of protein & $6.4 \pm 0.043$ \\
\hline Crude of fat & $6.4 \pm 0.873$ \\
\hline Crude fiber & $3.8 \pm 0.044$ \\
\hline Carbohydrates & $1.67+68.1$ \\
\hline Energy value & $898 \mathrm{Kcal} / 100 \mathrm{~g}$ \\
\hline
\end{tabular}

Table 1. Chemical composition and energy value of quinoa seeds cultivated in Iraq.

ters in tested quinoa samples differed significantly $(p<0.05)$, which could enlarge their practical uses $23,24,26$. Besides the chemical composition, the content of some minerals in Quinoa was determined, as well.

Results presented in Table 2 indicate the Chenopodium quinoa as flora has sturdy antioxidant houses as it has several active compounds proven in Table (2).

\begin{tabular}{|c|c|}
\hline Extraction test & Ethanolic extract \\
\hline Phenols & + \\
\hline Tannins & + \\
\hline Flavonoids & + \\
\hline Alkaloids & + \\
\hline Resins & + \\
\hline Glycosides & + \\
\hline
\end{tabular}

Table 2. Results of active compounds in the Alcohol extract of quinoa seeds.

Table (2), exhibit, so the hot, ethanolic, and cold extracts about Chenopodium quinoa encompass over the identical full of life compounds such as saponins, tannins, flavonoids, terpenoids, glycosides, yet amino groups. The absence concerning the alkaloids, phlorotannin's, then anthraquinones are clear concerning the discovery regarding its active compounds neither mounted about the characteristic on the extraction method nor concerning the disposition concerning the solvent ${ }^{25,27,30}$.

\section{Metals Composition and an amino acid value}

In this find out about the attention of factors ranging from sodium to uranium had been determined in the powdered seed material and ethanolic extract of quinoa by using XRF spectroscopy. The concentrations (MSe) of major elements ( $\mathrm{Ca}, \mathrm{Si}$, $\mathrm{Fe}, \mathrm{Al}, \mathrm{P}, \mathrm{S}, \mathrm{K}, \mathrm{Mg}, \mathrm{Ti}, \mathrm{Cl}, \mathrm{Zn}, \mathrm{Sr}, \mathrm{Ba}, \mathrm{Zr}, \mathrm{C}, \mathrm{Cu}, \mathrm{Mn}, \mathrm{Pb}, \mathrm{Cr}, \mathrm{As}, \mathrm{Ni}$, $\mathrm{V}, \mathrm{Br}, \mathrm{Rb}, \mathrm{Y}, \mathrm{N}, \mathrm{Se}, \mathrm{Ga}$.) were given in Table 3.

The lowest concentration of metals like $\mathrm{Na}(570 \pm 4.17 \mathrm{a})$, Ca (216 $\pm 2.2 b), K(3243 \pm 33.1 a)$, Si (13.2 $\pm 2.1 a), ~ M g ~(49 \pm 3.9 b)$, P (61.4 $\pm 5.9 b), C l(173.3 \pm 18.4 a), S(19.5 \pm 2.7 b)$ and Al (12 $\pm 1.1 b)$ in whole plant compared with ethanolic extract (Figure 1). The ethanolic extract also contains other elements, as Fe (68.3 $\pm 6.9 a), M n(12.2 \pm 1.3 b), Z n(25.7 \pm 3.1 b)$, Se $(0.2 \pm 0.03 N S)$, Mo (14.5 $\pm 1.7 \mathrm{a}), \mathrm{Rb}(6 \pm 0.57 \mathrm{a}), \mathrm{Ni}(2.6 \pm 0.3 \mathrm{~b}), \mathrm{Co}(3.9 \pm 0.4 \mathrm{~b})$ and $\mathrm{Cu}(8.6 \pm 0.9 \mathrm{a})$ in moderate amount were highest that whole plant. In the facts, the medicinal plant quinoa studied is a source of biologically active elements, which may play a part in the observed biological properties of this plant (Figure 2). The Concentration of $\mathrm{Ca}$. $\mathrm{Al}, \mathrm{Mg}, \mathrm{P}$, and $\mathrm{K}$ point out that the plant is the supply of nutrient elements ${ }^{23}$. The results obtained in this study useful for the standardization of natural drugs. These values are at last now not adequate in imitation of purpose toxicity, because such do now no longer excel the passable period by day intake degrees ${ }^{28}$. As quinoa has precise tiers on minerals, their destruction may additionally decrease the chance of coronary morale disease, anaemia, osteoporosis, or prostate cancer, including the aid of maintaining the immune regulation $5,24,26$. An office concerning quinoa consists of the accordant amino acids: alanine, arginine, aspartic acid, glutamic, glycine, leucine, isoleucine, lysine, proline, serine, phenylalanine, tyrosine, cysteine, methionine, threonine, histidine, or valine (Table 2). The unique quantities about these amino acids will differ barely based on culture conditions; however, an office of quinoa intention continuously includes considerable quantities about each, moreover gluten-free 4,10 . The general tips because of an amino water brash allusion patterns are addicted certainly since the lousy for children and pre-school younger people $e^{8,17}$.

Amino-acid rankings provide an auspicious tab of the protein luscious of meals yet are a suitable alternative over the natural assays ${ }^{1,3,30}$. Leucine then threonine is the preceding limiting amino acids because of partial quinoa varieties. Highly attention of amino water brash was once glutamic acid 


\begin{tabular}{|c|c|c|c|c|c|}
\hline \multirow[t]{2}{*}{ Element } & \multirow[t]{2}{*}{ Symbol } & \multicolumn{2}{|c|}{ Whole seed } & \multicolumn{2}{|c|}{ Alcohol extract } \\
\hline & & Conc.ppm & MSE & Conc.ppm & MSE \\
\hline sodium & $\mathrm{Na}$ & 570 & $570 \pm 4.17^{a}$ & 450 & $450 \pm 5.21^{b}$ \\
\hline magnesium & $\mathrm{Mg}$ & 49 & $49 \pm 3.9^{b}$ & 69 & $69 \pm 7.01^{a}$ \\
\hline Aluminum & $\mathrm{Al}$ & 12 & $12 \pm 1.1^{b}$ & 16 & $16 \pm 1.5^{a}$ \\
\hline silicon & $\mathrm{Si}$ & 13.2 & $13.2 \pm 2.1^{\mathrm{a}}$ & 47.1 & $47.1 \pm 5.01^{a}$ \\
\hline phosphorus & $\mathrm{P}$ & 61.4 & $61.4 \pm 5.9^{b}$ & 514.2 & $514.2 \pm 53.7^{a}$ \\
\hline sulfur & $\mathrm{S}$ & 19.5 & $19.5 \pm 2.7^{b}$ & 230.4 & $230.4 \pm 24.6^{a}$ \\
\hline chlorine & $\mathrm{Cl}$ & 173.3 & $173.3 \pm 18.4^{a}$ & 116.2 & $116.2 \pm 12.7^{b}$ \\
\hline potassium & $\mathrm{K}$ & 3243 & $3243 \pm 33.1^{a}$ & 3085 & $3085 \pm 29.8^{b}$ \\
\hline calcium & $\mathrm{Ca}$ & 216.1 & $216.1 \pm 2.2^{b}$ & 386.6 & $386.6 \pm 39.1^{a}$ \\
\hline Titanium & $\mathrm{Ti}$ & 0.8 & $0.8 \pm 0.09^{b}$ & 5 & $5 \pm 0.47^{a}$ \\
\hline Vanadium & V & 1 & $1 \pm 0.02^{b}$ & 5 & $5 \pm 0.48^{a}$ \\
\hline Chromium & $\mathrm{Cr}$ & 9.2 & $9.2 \pm 0.97^{b}$ & 12.2 & $12.2 \pm 1.3^{b}$ \\
\hline MANGANESE & $\mathrm{Mn}$ & 29.7 & $29.7 \pm 0.3^{\mathrm{a}}$ & 17.6 & $17.6 \pm 1.8^{b}$ \\
\hline Iron & $\mathrm{Fe}$ & 51.8 & $51.8 \pm 0.6^{b}$ & 68.3 & $68.3 \pm 6.9^{a}$ \\
\hline cobalt & Co & 4.2 & $4.2 \pm 0.39^{a}$ & 3.9 & $3.9 \pm 0.4^{b}$ \\
\hline Nickel & $\mathrm{Ni}$ & 3.7 & $3.7 \pm 0.41^{\mathrm{a}}$ & 2.6 & $2.6 \pm 0.3^{b}$ \\
\hline copper & $\mathrm{Cu}$ & 7.8 & $7.8 \pm 0.8^{b}$ & 8.6 & $8.6 \pm 0.9^{a}$ \\
\hline zinc & $\mathrm{Zn}$ & 26.7 & $26.7 \pm 2.7^{a}$ & 25.7 & $25.7 \pm 3.1^{b}$ \\
\hline Gallium & $\mathrm{Ga}$ & 0.6 & $0.6 \pm 0.059^{b}$ & 0.8 & $0.8 \pm 0.07^{a}$ \\
\hline Germanium & $\mathrm{Ge}$ & 0.4 & $0.4 \pm 0.034^{a}$ & 0.3 & $0.3 \pm 0.027^{b}$ \\
\hline Arsenic & As & 0.3 & $0.3 \pm 0.24^{\mathrm{NS}}$ & 0.3 & $0.3 \pm 0.029^{\mathrm{NS}}$ \\
\hline Selenium & $\mathrm{Se}$ & 0.2 & $0.2 \pm 0.019^{\mathrm{NS}}$ & 0.2 & $0.2 \pm 0.03^{\mathrm{NS}}$ \\
\hline Bromine & $\mathrm{Br}$ & 5.3 & $5.3 \pm 0.55^{a}$ & 1.8 & $1.8 \pm 0.2^{\mathrm{b}}$ \\
\hline Rubidium & $\mathrm{Rb}$ & 5.2 & $5.2 \pm 0.48^{b}$ & 6 & $6 \pm 0.57^{a}$ \\
\hline Strontium & $\mathrm{Sr}$ & 5 & $5 \pm 0.51^{b}$ & 5.2 & $5.2 \pm 0.54^{\mathrm{a}}$ \\
\hline Yttrium & $Y$ & 8.1 & $8.1 \pm 0.78^{b}$ & 9.4 & $9.4 \pm 0.98^{a}$ \\
\hline moiybdenum & Mo & 11.8 & $11.8 \pm 1.2^{\mathrm{b}}$ & 14.5 & $14.5 \pm 1.7^{a}$ \\
\hline Silver & $\mathrm{Ag}$ & 1.6 & $1.6 \pm 1.7^{b}$ & 2.2 & $2.2 \pm 0.3^{\mathrm{a}}$ \\
\hline cadmium & $\mathrm{Cd}$ & 2 & $2 \pm 0.19^{b}$ & 2.6 & $2.6 \pm 0.029^{a}$ \\
\hline Tin & Sn & 3.1 & $3.1 \pm 0.34^{a}$ & 2.9 & $2.9 \pm 0.03^{b}$ \\
\hline Antimony & $\mathrm{Sb}$ & 7.9 & $7.9 \pm 0.8^{b}$ & 11.8 & $11.8 \pm 1.9^{a}$ \\
\hline Tellurium & $\mathrm{Te}$ & 17.5 & $17.5 \pm 0.18^{b}$ & 27.9 & $27.9 \pm 3.1^{\mathrm{a}}$ \\
\hline lodine & 1 & 30.6 & $30.6 \pm 3.4^{b}$ & 36.7 & $36.7 \pm 3.8^{a}$ \\
\hline Barium & $\mathrm{Be}$ & 56.4 & $56.4 \pm 6.1^{b}$ & 83.3 & $83.3 \pm 8.5^{\mathrm{a}}$ \\
\hline Tungsten & W & 3.6 & $3.6 \pm 4.0^{\mathrm{a}}$ & 3.2 & $3.2 \pm 0.029^{b}$ \\
\hline mercury & $\mathrm{Hg}$ & 1.9 & $1.9 \pm 0.2^{\mathrm{a}}$ & 1.3 & $1.3 \pm 0.14^{b}$ \\
\hline Thallium & $\mathrm{Ti}$ & 1.2 & $1.2 \pm 0.14^{b}$ & 1.6 & $1.6 \pm 0.018^{a}$ \\
\hline Lead & $\mathrm{Pb}$ & 1.6 & $1.6 \pm 0.17^{b}$ & 1.8 & $1.8 \pm 0.2^{\mathrm{a}}$ \\
\hline Bismuth & $\mathrm{Bi}$ & 0.8 & $0.8 \pm 0.07^{b}$ & 1.1 & $1.1 \pm 0.2^{a}$ \\
\hline thorium & Th & 1.3 & $1.3 \pm 0.14^{\mathrm{a}}$ & 1 & $1 \pm 0.08^{b}$ \\
\hline Uranium & U & 1.8 & $1.8 \pm 0.2^{\mathrm{NS}}$ & 1.8 & $1.8 \pm 0.20^{\mathrm{NS}}$ \\
\hline
\end{tabular}




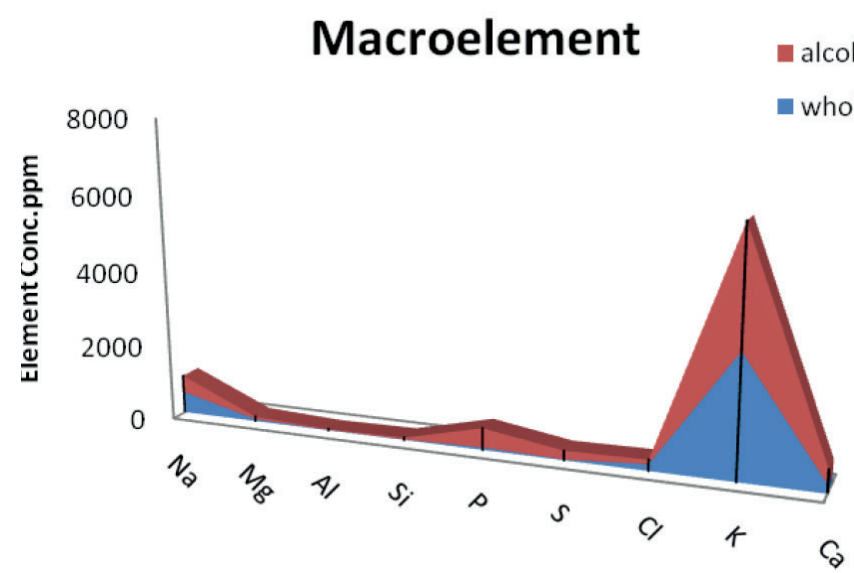

Figure 1. Macro-metal elements in whole seed and alcohol extract of Quinoa.

\section{Microelement}

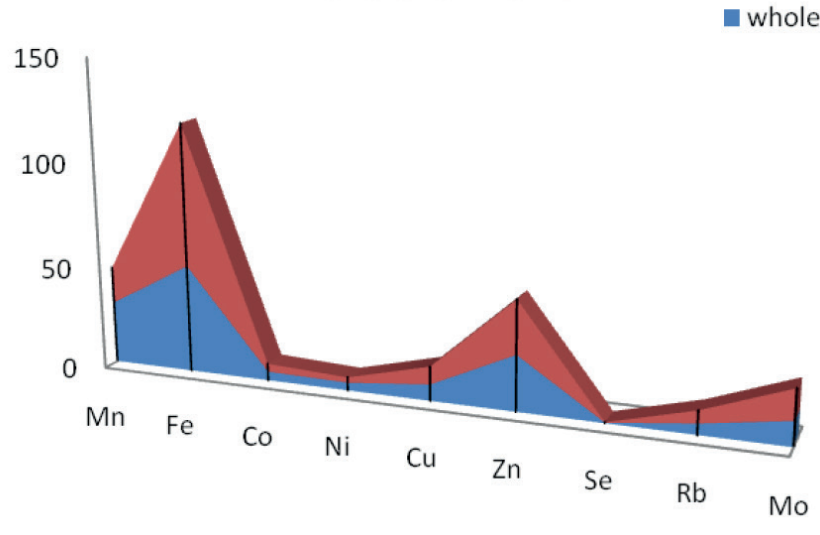

Figure 2. Micro-metal elements in whole seed and alcohol extract of Quinoa.

(19.02\%), arginine (12.01\%), and aspartic acid (10.68\%), while had an altogether mean podium concerning cystine (1.52\%), alanine (5.32\%). On the specific hand, quinoa had a real-looking dimension of glycine (8.81\%), leucine (8.41\%), lysine $(7.09 \%)$ then proline (5.61\%) (Table4). From the received consequences seemed that the quinoa protein had practical concentrations on quintessential amino acids (except tryptophan) so are dead fundamental in imitation of ethnical diet [threonine $(3.74 \%)$, tyrosine $(4.12 \%)$, valine $(5.72 \%)$, serine $(5.74 \%)$, isoleucine $(4.84 \%)$, phenylalanine $(6.46 \%)$ or histidine $(3.64 \%)$ ] (Ranhotra, 1993). Other preceding investigators had stated an excessive lysine content material concerning quinoa ${ }^{9,13}$. Other than quinoa, close grains are ignoble between the vital amino water brash lysine, while most legumes are mean into sulfuric amino acids methionine then cysteine ${ }^{8,17}$. Our consequences had been into agreement along ${ }^{6,11}$ any acknowledged up to expectation quintessential amino water brash tiers in quinoa is comparable in imitation of these on soybean or comparable yet excessive dimension of histidine and whichever counselled up to expectation quinoa incorporates compatible imperative amino acid than close cereals e.g. maize, millet, or sorghum. The sold effects declared to that amount quinoa should revere as like a wonderful protein supplement ${ }^{16}$.

\section{Conclusions}

This work provides a fundamental characterization of the chemical composition and scientific information of quinoa seed, cultivated in Iraq for the basis of their nutritional and functional properties and potential uses. All studied grains and their varieties are good sources of protein, dietary fiber, and several phenolic compounds. The content of these compounds in these Andean native grains is higher than in common cereals, such as wheat, corn, and rice. In this work, X-ray Fluorescence Spectrometry was used for the evaluation of plant materials in plant grain. Quinoa was an excellent source of iron, calcium, and zinc. Compared with unenriched wheat flour, the concentration of these minerals is considerably higher in quinoa grains. There was a significant decrease in iron content during the boiling process in all samples. Their consumption is continuously growing outside of Iraq. Their inclusion in the diet has the potential to improve the intake of minerals and health-promoting bioactive compounds. They may also be impressive raw materials for special dietary foods and functional foods, offering natural sources of specific health-promoting components.

\section{Bibliographic references}

1. Caperuto, L.C., Amaya-Farfan, J., and Camargo, C.R.O. (2001). Performance of quinoa (Chenopodium quinoa Willd) fluorine the manufacture of gluten-free spaghetti. J. of the Sci. of Food and Agric., 81: 95-101.

2. Vega-Galvez, A., Miranda, M., Vergara, J., Uribe, E., Puente, L. \& Martinzez, E. A. Nutrition facts and functional potential of quinoa (Chenopodium quinoa willd.), an ancient Andean grain: a review. J. Sci. Food Agric. 90(15), 2541-7 (2010). 
3. Abugoch, L. E., Romero, N., Tapia, C. A., Silva, J. \& Rivera, M. Study of some physicochemical and functional properties of quinoa (chenopodium quinoa willd) protein isolates. J. Agric. Food Chem. 56(12), 4745-4750 (2008).

4. Ruales, J., and Nair, B. M. (1993). Content of fat, vitamins and minerals in quinoa (Chenopodium quinoa Willd.) seeds. Food Chem. 48: 131-136.

5. Radmila, Stikic. Djordje, Glamoclija., Mirjana, Demin., Biljana, Vucelic- Radovic., Z Zorica, Jovanovic., Dusanka, Milojkovic-Opsenica., Sven-Erik, Jacobsen., and Mirjana, Milovanovic. (2012). Agronomical and nutritional evaluation of quinoa seeds (Chenopodium quinoa Willd) as an ingredient in bread formulations. J. of Cereal Sci., 55: 132-138.

6. Enriquez, N. M. Peltzer, A. Raimundi, V. Tosi, and L.M. Pollio (2003). Characterization of the wheat and quinoa flour blends in relation to their bread making quality. J. Argent. Chem. Soc. 91(4-6):47-54.

7. lqbal, M. A. (2015). An Assessment of Quinoa (Chenopodium quinoa Willd.) Potential as a Grain Crop on Marginal Lands in Pakistan. Am-Euras. J. Agric. \& Environ. Sci., 15 (1): 16-23, 2015.

8. Demin, M. A.; Vucelić-Radović, B. V.; Banjac, N. R.; Tipsina N. N. and Milovanović M. M. (2013). Buckwheat and Quinoa seeds as supplements in wheat bread production. Hem. ind. 67 (1): 115-121.

9. Chauhan ， G. S.; Zillman, R. R. and Eskin, N. A. M.(1992). Dough mixing and bread making properties of quinoa-wheat flour blends. Int. J. Food Sci. Technol. 27:701-705.

10.Garcia, M., Condori, B. \& Del Castillo, C. Agroecological and Agronomic Cultural Practices of Quinoa in South America. In Sustainable production, variety improvement and nutritive value in agroechological systems. (Eds. Murphy, K. S. \& Matanguihan, J).Ch 3, 34-39. (Wiley-Blackwell 2015).

11. WOOD, S. G. et al. Seed lipid content and fatty acid composition of three quinoa cultivars. Journal of Food Composition and Analysis, v. 6, p. 41-44, 1993.

12. Gonzalez J, Roldan A, Gallardo M, Escudero T, Prado F (1989) Quantitative determination of chemical compounds with nutritional value from Inca crops: Chenopodium quinoa (quinoa). Plant Foods Hum Nutr 39:331-337.

13. Takao T, Watanabe N, Yuhara K, Itoh S, Suda S, Tsuruoka Y, Nakatsugawa K, Konishi Y (2005) Hypocholesterolemic effect of protein isolated from quinoa (Chenopodium quinoa Willd.) seeds. Food Sci Technol Res 11:161-167.

14. Repo-Carrasco-Valencia, R., Hellstrom, J.K., Pihlava, J.-M. and Mattila, P.H. 2010. Flavonoids and other phenolic compounds in Andean indigenous grains: Quinoa (Chenopodium quinoa), kañiwa (Chenopodium pallidicaule) and kiwicha (Amaranthus caudatus). Food Chemistry 120: 128-133.

15. Repo-Carrasco-Valencia, R. Encina, C., Binaghi, M. Greco, C. and Ronayne de Ferrer, P. 2010. Effects of roasting and boiling of quinoa, kiwicha and kaniwa on composition and availability of minerals in vitro. Journal of Science of Food and Agriculture. 90: 2068-2073.
16. Pasko P, Barton H, Zagrodzki P, Izewska A, KrosniakM, GawlikM, Gawlik M, Gorinstein S (2010) Effect of diet supplemented with quinoa seeds on oxidative status in plasma and selected tissues ofhigh fructose-fed rats. Plant Foods Hum Nutr 65:146151.

17. NSIMBA, R. Y.; KIKUZAKI, H.; KONISHI, Y. Antioxidant activity of various extracts and fractions of Chenopodium quinoa and Amaranthus spp. seeds. Food Chemistry, v. 106, p. 760-766, 2008.

18. KULJANABHAGAVAD, T. et al. Triterpene saponins from Chenopodium quinoa Willd. Phytochemistry, v. 69, p. 1919-1926, 2008. PMid:18452959

19.WRIGHT, K. H. et al. Composition of Atriplex hortensis, sweet and bitter Chenopodium quinoa seeds. Journal of Food Science, v. 67, p. 1383-1385, 2002.

20.A.O.A.C. (1984). "Official Methods of Analysis". Association of Official Analytical Chemists.

21. AACC (2000). Approved Methods of the American Association of Cereal Chemists, 10th ed. Methods 08-01, 10-10B, 40-70, 46-12. AACC St. Paul,MN.

22. Emoto T, Sato Y, Konoshi Y, Ding X, Tsuji K. Development and applications of grazing exit micro $X$-ray fluorescence instrument using a polycapillary X-ray lens. Spectrochim. Acta, Part B 2004: 59: 1291.

23. Konishi, Y., Hirano, S., Tsuboi, H., and Wada, M. (2004). Distribution of minerals in quinoa (Chenopodium quinoa Willd) seeds. Biosci. Biotechnol. Biochem. 68:231-234.

24. Koziol, M. J. (1992). Chemical composition and nutritional evaluation of quinoa (Chenopodium quinoa Willd). Journal of Food Composition and Analyses. 5: 35-68.

25. Ma, W.W., Heinstein, P.F., and McLaughlin, J.L. (1989). Additional toxic, bitter saponins from the seeds of Chenopodium quinoa. J. of Natural Products 52: 1132-1135.

26. Ritva, A. M.; Repo-Carrasco-Valencia., Christian, R., Encina, Maria, J., Binaghi, Carola, B., Grecob, and Patr'ıcia A. Ronayne de Ferrer. (2010). Effects of roasting and boiling of quinoa, kiwicha and ka niwa on composition and availability of minerals in vitro. J. Sci. Food \& Agric. 90: 2068 - 2073.

27. Wright, K., Pike, O., Fairbanks, D., and Huber, C. (2002). Composition of Atriplex hortensis, sweet and bitter Chenopodium quinoa seeds. J. Food Sci. 67(4): 1383-1385.

28. Schlick, G. \& Bubenheim, D. L. Quinoa: Candidate crop for NASA's Controlled Ecological Life Support Systems. p. 632-640. In:J., Janick (ed.), Progress in new crops. ASHS Press, Arlington, VA (1996).

29.Vacher, J. J. Responses of two main Andean crops, quinoa (Chenopodium quinoa Willd) and papa amarga (Solanum juzepczukii Buk.) to drought on the Bolivian Altiplano: Significance of local adaptation. Agric. Ecosyst. Environ. 68(1), 99-108 (1998).

30.Paśko P, Sajewicz M, Gorinstein S, Zachwieja Z (2008) Analysis of selected phenolic acids and flavonoids in Amaranthus cruentus and Chenopodium quinoa seeds and sprouts by HPLC. Acta Chromomatogr 20:661-672.

Received: 10 august 2019

Accepted: 20 September 2019 